\title{
'We ring this round with our invoking spells': Magic as embedded authorship in The Merry Devil of Edmonton
}

\section{Peter Kirwan, University of Nottingham}

\section{Introduction}

The anonymous The Merry Devil of Edmonton, first published 1608, would seem an obvious place to begin looking for representations of magic in Renaissance drama. This Chamberlain's/King's Men's play draws on folk legends of Peter Fabell, a scholar and conjuror who 'for his fame in sleights and magic won,/ Was called the merry fiend of Edmonton' (Prologue 14-15). ${ }^{1}$ The Induction stages a contest between Fabell and a spirit, Coreb, in which the witty Fabell wins seven more years of life. Yet after this set-up, as the play's most recent editor notes, 'Fabell's role in the action seems rather marginal, as

the play exploits his magical powers less than one might expect. He performs in fact only "pretty sleights" that "but sat upon the skirts of art". ${ }^{2}$ The play itself turns out to be a romantic comedy of young love, thwarted fathers and petty clowning. While Fabell promises to conjure 'fellows of a handful high' (2.2.88), 'spirits to dance such nightly jigs' (1.2.190) and 'such rings of mist/ As never rose from any dampish fen' (1.2.77), none of these magical phenomena are ever realised on stage, and his ingenious interactions with the plot are entirely natural.

Despite a title that promises magic, then, and an induction that stages necromancy, the play signally fails to deliver the implied spectacle. What is the purpose of the magic in this otherwise conventional comedy? This essay turns to the play's original theatrical context to address this problem. While much ink has been expended 
attempting to fit Merry Devil into an authorial canon, ${ }^{3}$ recent influential work in the area of repertory studies has urged us to reconsider plays as 'authored' by the playing company with whom they originated, prioritising a discursive network of influences over individual agency. ${ }^{4}$ Considering Merry Devil in this way places Fabell within a context of staged authorial debates, appropriating and then absorbing tropes of magic as a means of reconstituting and representing the Chamberlain's Men's ensemble ethos.

\section{Authorship and the ensemble}

While the play's induction is obviously indebted to Doctor Faustus, to which I shall return below, The Merry Devil of Edmonton must be seen more significantly as a thematic sequel to the company's older comedy The Merry Wives of Windsor, a text of which was first published 1602, the probable year of the first staging of Merry Devil. Aside from the shared structure of the two titles, deliberately drawing attention to the similarities, the play carefully rehearses the plot and characters of Merry Wives. Both are 'bourgeois' comedies, interweaving the domestic affairs of the affluent classes with the more comic activities of their servants. Both take place in out-of-town locales, close enough to London to avoid the stigma of provincial drama but far enough to soften the satire of contemporary city comedy. Both take place in an inn presided over by a genial Host; the primary plots of both centre round a pair of young lovers kept apart by parents for financial/social reasons; both stage climactic scenes in the confused environment of a forest at night.

These are substantial reminiscences rather than explicit retellings, but are part of a wider attempt to recreate Merry Wives without Falstaff. Falstaff's absence is specifically alluded to in the person of Host Blague, whose verbal tag, 'I serve the good Duke of 
Norfolk', reminds us of Falstaff's own service of Thomas Mowbray. ${ }^{5}$ Aspects of Falstaff are distributed between the Host (leader of the band of poachers): the comic Smug and the corrupt priest who bears his name, Sir John. Falstaff's failure to appear in Henry $V$ following the promise of the Epilogue in 2 Henry IV has been much remarked, and may owe something to the departure of Will Kempe c. $1599 .{ }^{6}$ Falstaff's disappearance from the stage did not go unfelt, however; the two-part Sir John Oldcastle (Admiral's Men, 1599) explicitly articulates the absence of Falstaff in its Prologue statement that 'It is no pamperd glutton we present,/ Nor aged Councellor to youthfull sinne' (Prologue 6-7). ${ }^{7}$ The absent presence of Falstaff is felt throughout Merry Devil too, the character evoked by several characters and situations but fully embodied by none. This is not dissimilar to the strategy adopted for the company's roughly contemporaneous Twelfth Night. While Feste appears to provide a role for Robert Armin, the play distributes the clowning between a number of characters, including Toby and Andrew. In Falstaff's absence, no one comic character is allowed to dominate the stage, suggesting a conscious company intent to prioritise ensemble practice over star individuals in comedies of this period. ${ }^{8}$

I dwell on the links between Merry Wives and Merry Devil because the earlier play's treatment of the supernatural on stage is telling in its influence on Merry Devil. Folk magic fills an important dramatic function at key moments in Merry Wives. Whether in Ford's recognition of Falstaff as the 'witch of Brentford' or, more obviously, in the final gulling of Falstaff at Herne's oak, the performance of magic and witchcraft acts to license extreme and transgressive behaviours. It acts as a narrative catalyst, allowing a physical punishment of Falstaff unthinkable within conventional modes of behaviour and, more relevantly, allowing parental will to be subverted in the case of Fenton and Anne. ${ }^{9}$ 
Fabell's 'magic' operates for this latter purpose in Merry Devil, thwarting the designs of Clare and Jerningham for their children and arranging for Raymond and Millicent to be wed via a similar strategy of disguise and night-time elopement.

In Merry Wives, however, magic is explicitly artificial. We are aware at all times that the witches, satyrs and fairies are disguised mortals. Magic is an effect of stage management, playing on credulity and superstitious belief. Stephen Greenblatt has argued that Shakespeare was well aware of discourses of scepticism towards witchcraft such as that of Reginald Scot, who associates the manifestation of devils with playhouse trickery. For Shakespeare, in Greenblatt's argument, this is figured as the source of artistic expression:

According to Scot, witchcraft is an illicit crossing of the threshold of figuration, a confused tangle of anxieties improperly given a local habitation and a name. Shakespeare's concern $[\ldots]$ is precisely to cross that threshold. [...] For Scot the passage from inchoate emotion to figuration - from fear or impatience or desire to an identifiable, luminously visible figure - is the source of evil; for Shakespeare it is the source of the dramatist's art. ${ }^{10}$

Discourses of magic are inextricably tied to discourses of authorship, both forms of transgression resulting in physical manifestations of creative activity, and both manifestly artificial. Stage magic thus offers a theatrical realisation of authorial activity. Jeffrey Knapp has argued that 'Shakespeare worked to develop specifically theatrical paradigms of authorship that would better reflect his professional engagement with his fellow actors and his mass audience'; ${ }^{11}$ that is, that a recurrent motif throughout Shakespeare's works is the embedding of theatrical authorship into the fabric of the plays. It is the embedding 
that is key and specific to Shakespeare's treatment rather than the more widespread staging of authorship throughout the drama of the period. 'It was the intensity of his immersion in the theater that created the effect of his singularity even in his own day'. ${ }^{12}$ This is evident within the wider repertory of the Chamberlain's Men - the company that appears to have pioneered the idea of an embedded dramatist - most prominently in Dekker's Satiromastix, which stages the untrussing of the garrulous Horace for selfexhibition at the playhouse. ${ }^{13}$

In Shakespeare, in Satiromastix and in the wider repertory of the Chamberlain's/King's Men during this period, the author is invoked only to be reintegrated. ${ }^{14}$ Authorship is figured as a generative and creative activity that is then dispersed and subsumed to the collective project rather than embodied in key authorial figures. Authorship is thus figured as serving the purposes of the community rather than the individual.

What, then, is the purpose of reinstituting discourses of the supernatural at this time? Roslyn Knutson argues that there were several plays about magicians in performance in 1602-3; but the evidence suggests that these (including The Wise Men of West Chester, Faustus and a play called 'Bacon', all by the Admiral's Men) were all revivals of plays from the early 1590 s. The commissioning of a new play with an ostensibly magical theme might appear to be opportunistic, but the choice to substantially rework a comedy in which magic had featured as a transparent charade, and then to include very little magic in the play, seems designed to distinguish Merry Devil from the sudden resurgence in magical interest rather than align the play with it. Yet by playing on the audience's familiarity with stage tropes of magic and the occult, the dramatist is able 
to appropriate their associations with authorial activity to draw attention to the company's current focus on ensemble creativity.

\section{Outdoing Faustus}

Knutson identifies the revival of Marlowe's Faustus at the Rose in the winter of 1602-3 as a key reference point for the first performances of Merry Devil. ${ }^{15}$ The popular play, to which Rowley and Bird had recently contributed additions, is an obvious touchstone for Fabell; as Knutson says, 'in the induction of the Chamberlain's play, Peter Fabell is not the wise man of West Chester or Friar Bacon but Doctor Faustus', ${ }^{16}$ and Barbara Howard Traister argues that '[w]ithout the audience's knowledge of Faustus, this scene would lose much of its titillation and impact'. ${ }^{17}$ The link to the damned scholar is made clear from Fabell's opening lines:

What means the tolling of this fatal chime?

Oh what a trembling horror strikes my heart!

My stiffen'd hair stands upright on my head

As do the bristles of a porcupine. (Induction 1-4) ${ }^{18}$

Faustus epitomises the conjuror-as-author motif, later revisited in a more benign capacity in Prospero; ${ }^{19}$ as D.J. Palmer argues, Marlowe's play demonstrates 'that the drama, particularly the poetic drama, is itself a kind of enchantment' ${ }^{20}$ Faustus is the author of a series of comic interludes, manipulating the Pope and Cardinals, the German Emperor's courtiers and the clowns in sequences of humiliation; then later, he explicitly writes his own tragedy in blood, drawn from his own arm, an action copied by Fabell. ${ }^{21}$ These acts of writing and playmaking turn the author into the subject, Faustus becoming the primary player as well as play-maker. Magic is the medium of dramatic creation; spectacle its 
output; the foregrounding of the author its objective. It is this sense of magic that the Prologue of Merry Devil invokes in its appeal for the audience's attention:

That your free spirits may with more pleasing sense

Relish the life of this our active scene;

To which intent, to calm this murmuring breath,

We ring this round with our invoking spells. (Prologue 2-5)

Magic is invoked by the meta-theatrical authorial voice that introduces the performance in order that the play may literally be made; it creates the conditions of attention necessary for the theatrical experience to occur, and is thus understood from the beginning as emblematic of authorship. ${ }^{22}$ Yet the contrast to the use of magic in Faustus is already marked. In Marlowe's play, as Palmer argues, 'Faustus' illusion of demonic power over nature is both image and sources of the drama's hold upon its spectators' ${ }^{23}$ The image is one of control and individual dramatic control. However, the silence invoked by 'magic' in Merry Devil still draws attention to the playmaker, but here that maker is plural; the invoking spells are 'ours', the company's. Where magic for the Admiral's Men's play is utilised for the benefit of the author-substitute and his patrons, here magic is invoked for the shared pleasure of the collective authorial body and the assembled auditors. Magic binds author(s) and audience in a mutual contract, rather than subjecting audiences to the tyranny of the domineering Author.

The Prologue introduces the only sustained period of necromantic activity in the play by strategically juxtaposing familiar devices with acknowledgement of artifice. A curtain is drawn, and the Prologue describes the 'restless couch', the 'fatal chime', 'sable sleights' and the 'necromantic chair/ In which he makes his direful invocations/ And 
binds the fiends that shall obey his will'. However, the Prologue then immediately requests the audience

Sit with a pleased eye until you know

The comic end of our sad tragic show. (Prologue 35-42)

Magic is described in terms of its theatrical props and performative aspects, couched between appeals to the auditors that subvert the visual associations familiar to audiences of Faustus. In a single line, the generic model of the play is inverted, turning the expected 'tragic show' to a promised 'comic end'. The effects of necromancy, inevitable in Faustus, are shown here to be subject to authorial 'art', available for re-inscribing in the author's chosen mode. This juxtaposition continues throughout the scene. Fabell invites Coreb to sit in his necromantic chair before delivering his soliloquy on the consequences of sorcery. The conventional damnation narrative continues even after the actions necessary to subvert it have been taken, and magical agency is thus introduced in tandem with authorial privilege. Coreb's furious 'A vengeance take thy art!' (Induction 75) is ambiguously directed both at Fabell's magic and at his rewriting of the narrative that banishes him.

The subsequent subsumption of Fabell's magic into the collaborative social networks of comedy is set up in Fabell's final address to Coreb:

Then thus betwixt us two this variance ends,

Thou to thy fellow fiends, I to my friends. (Induction 83-4)

The 'merry fiend' abjures his own fiendish associations in place of 'friends', socialising the magician in a manner abjured by Faustus, whose mortal companions drop away as the play progresses. By the time of Fabell's next appearance, he is already in (the) company. 
Yet he remains without family attachments, according him a relative solitude within the social group that allows him to become a locus of responsibility for the plot. In the event, none of Fabell's stratagems are required. He promises that his spirits will create confusion that will lead everyone astray; ${ }^{24}$ yet in the event, it is merely the dark that causes Millicent, Harry and Frank to lose their way and cross paths with the poachers of Act $4 .{ }^{25}$ Similarly, his promises that the nuns will be made to skip, play leap-frog, run around naked and pinch one another are not realised, and instead are replaced by simply disguising Raymond as a friar in order that he can visit Millicent in the nunnery. Expectations of magic are repeatedly deflated and replaced by conventional dramatic tricks masterminded by Fabell. Magic, that is, is rendered unspectacular. ${ }^{26}$

The only explicitly magical aspect of Fabell's contribution is, in fact, also the most explicitly authorial. In 1.2, Fabell arrives at the George and is introduced to Sir Arthur Clare, who makes a single disparaging remark about Raymond, and within twenty lines Fabell is left alone onstage. In soliloquy, he reveals that he is aware of the compact between Clare and Jerningham to thwart Raymond and Millicent's courtship and their motives. When his three friends re-enter, it is then Fabell who reports to Frank that the match has now (ie while he has been alone onstage) been made; that Frank is to marry Millicent; and that Millicent is to be sent to the nunnery. With the young generation armed with the knowledge, Fabell announces that 'Age and craft with wit and art have met' (1.2.189), and is in a position to stage his rewriting of the fathers' plot.

Fabell's true magic is an authorial privilege; he has an entire overview of the narrative, knowing what is and what will happen. The absence of the manifestly supernatural throughout the play allows this power to remain benevolent: the 'merry 
devil' is not a trickster but a plotter, describing the action and casting players to perform it. Fabell himself is absent for all the key action: the liberation of Millicent, the escape through the forest, the switching of inn signs to confuse the fathers. Instead, as Joseph Horrell points out, his 'infrequent appearances do not project him with any of the appurtenances or characteristics of the necromancer'. ${ }^{27}$ Instead, he arrives at the conclusion of episodes, approving the interlude and instructing his players on their next scene. That is, he performs the role of the embedded author. ${ }^{28}$

\section{Cooperation and Competition}

The embedded author-magician is motivated cooperatively rather than competitively. ${ }^{29}$ The battle for magical supremacy is a feature of most major necromantic plays. Most notably, Friar Bacon and Friar Bungay features a number of duels, from Bacon striking Bungay dumb in scene 6 to the three-way duel in scene 9 between Bacon, Bungay and Vandermast. The exertion of aggressive and spectacular magic is the means by which magicians establish their individual precedence and authority; significantly, Bungay's enforced muteness deprives him of his ability to perform Lacy and Margaret's wedding: 'Fear not, my lord, I'll stop the jolly Friar / For mumbling up his orisons this day' (6.14950). ${ }^{30}$ In being unable to speak, Bungay is also rendered unable to perform magic, ceding supremacy in this context to the absent Bacon. Here, the magician's function within society is dependent on his self-assertion; his position must be fought for and maintained against the invasive actions of other magicians.

It is significant, then, that in the Bacon and John a Cumber plays, magicians are invariably associated with political power. In Friar Bacon and Friar Bungay, the Emperor of Germany employs Vandermast as part of his entourage specifically in order 
that he may 'dispute' (4.46) with the best of the Oxford doctors. While the magicians are, in this political environment, ostensibly serving the ends of their masters, their usefulness is determined by their individual fame and their relative merits. As King Henry tells Vandermast,

In Oxford shall thou find a jolly friar, Call'd Friar Bacon, England's only flower.

Set him but nonplus in his magic spells, And make him yield in mathematic rules, And for thy glory I will bind thy brows, Not with a poet's garland made of bays, But with a coronet of choicest gold. (4.59-65)

This innocuous but determined political action depends on Bacon's fame and supremacy ('only flower'), and Vandermast's ability to 'make him yield'. Henry promises Vandermast 'thy' glory, although his evocation of Bacon's nationality ('England's only flower') reminds us that Vandermast's glory is ultimately Henry's. Most interestingly, however, Henry explicitly offers to crown his necromancer 'not with a poet's garland' but with the more materially valuable golden coronet. Henry's denial of the poet's garland asserts the connection between poet and magician even as it attempts to sever it; Vandermast's anticipated victory would, by default, be understood in terms of a victory of poetry, but Henry offers an ostensibly more valuable reward that differs in kind as well as quality, reclaiming Vandermast's victory as an assertion of political and capital power rather than artistic achievement. 
The assertion of individual agency is as true of Faustus, who initially seeks to dispute with Mephistopheles for the kinds of power he is able to exercise. Indeed, one of Faustus's first disappointments is in the qualification of the kind of power and knowledge that his necromancy may afford him.

FAUSTUS. Tell me who made the world.

MEPHISTOPHELES. I will not.

FAUSTUS. Sweet Mephistopheles, tell me.

MEPHISTOPHELES. Move me not, Faustus.

FAUSTUS. Villain, have not I bound thee to tell me any thing?

MEPHISTOPHELES. Ay, that is not against our kingdom.

This is. Thou art damned. Think thou of hell. (B-text 2.3.66-73)

Faustus's early scenes with Mephistopholes are concerned with establishing the limits of his power. Earlier, Mephistopholes brings in Devils who dance for Faustus and give him 'crowns and rich apparel', which Mephistopholes says were provided 'to delight thy mind / And let thee see what magic can perform' (B-text 2.1.83.1-85). In hindsight, 'can' - which Faustus presumably glosses as 'is able to' - translates as 'may'; Mephistopholes is prescribing the limits within which Faustus's magical self-assertion can occur. Faustus is licensed to use magical showmanship for his own self-aggrandisement, but is forbidden to approach divine mysteries or knowledge unauthorised by his patrons. ${ }^{31}$ His magic is circumscribed by the same means as Vandermast's; while both conjurors depend on their individual fame and advance magic for their own entertainment and competition, their magic continues to belong to their masters. 
Following the Induction, Fabell's magic belongs to his fellows rather than his masters. When Coreb enters, he tells Fabell that the date of thy command is out And I am master of thy skill and thee. (Induction 32-33)

Fabell's subsequent mastering of Coreb is an attempt to gain 'liberty', and upon success he announces that 'this variance ends' (Induction 70, 83). Regardless of whether or not we are to keep in mind Coreb's threat that there will be no reprieve at the end of the next seven years, there is a marked difference in Fabell's desires. Faustus paradoxically cedes his own individuality by enslaving himself to the Devil in order to better assert his own fame in the short term; so too on a political level does Vandermast, whose fame is in thrall to his German lords. Fabell, however, seeks to be masterless and to return to his friends; his liberty is bound to a community investment. This is implicitly akin to the humility of the repentant Bacon:

I'll spend the remnant of my life In pure devotion, praying to my God

That He would save what Bacon vainly lost. (13.106-08)

While Bacon's ceding to a higher authority is very different to Fabell's apparent 'liberty', both Fabell and Bacon recognise the 'vanity' of the fame won under self-aggrandising necromantic activity, 'when men in their own pride strive to know more than man should know!' (Merry Devil Induction 47). While Bacon's failure drives him to a different (albeit purer) form of political and religious service, however, Fabell chooses to subsume pride into the more anonymous assistance of friends and lovers. He forgoes patronage and, in doing so, retains his magical powers and individual agency in the humbler context 
of an anonymous play. What Traister identifies as the "modesty of his magic in his final speech" in contrast to his earlier "vaunt", I suggest is a deliberately politic decision to avoid the prioritisation of the individual. ${ }^{32}$ Where the art of Faustus, Bacon, Vandermast and others remains always an assertion of the self, Fabell's art is transformed into a representation of the ensemble's needs, the ends of the company of friends.

\section{A farewell to magic}

The mundane quality of Fabell's participation in the main action of Merry Devil is ultimately acknowledged by the conjurer himself:

I used some pretty sleights, but I protest

Such as but sat upon the skirts of art:

No conjurations, nor such weighty spells

As tie the soul of their performancy. (5.1.257-60)

It is in these lines that the action of the main play is finally linked to the Induction. While

critics such as Horrell assert the relative irrelevance of the Induction to the main play, ${ }^{33}$ Fabell's 'protest' here reminds us that the scholar has, despite the trick played on Coreb, only bought himself a temporary respite of seven years. Fabell's discourse in the Induction on the danger of 'the infinity of arts' (Induction 49) is here brought full circle; Fabell is insistent that his works do not constitute art, conjuration or spells. His ends have, instead, been achieved through a lighter form of performance that does not further endanger his soul. The damned magician here dissociates his own fate from the natural works of the comedy.

Several years ahead of The Tempest, then, Peter Fabell enacts the end of magic. This benign necromancer bridges the gap between Faustus and Prospero, and in doing so 
gives the lie to readings of the more famous conjurers that seek to link them biographically or ideologically to the authors they typify, whether in Faustus's/Marlowe's blasphemy or Prospero's/Shakespeare's benign oversight. ${ }^{34}$ The move away from spells is not manifested as spectacular self-destruction nor wilful abjuration. Rather, magic transcends authorial self-representation and is subsumed into the processes of plotting and practical action that require the embedded rather than auctorial involvement of the author/magician; magic is, in essence, re-characterised as the doing of good for others rather than the abuse of magic for one's self. As Fabell concludes,

Let our toil to future ages prove

The Devil of Edmonton did good in love. (5.1.268-69)

It is in the conclusion of the selfless action that the Devil is made Merry, bringing together 'friends' in a humble romance. Knutson notes that while earlier stage magicians such as Kent and Bungay 'usually take some part in the sorting out of marriage partners', invariably 'they have more interest in their own magical experiments and in duels with rival magicians'. ${ }^{35}$ While Bacon celebrates the marriage of Edward and Eleanor, his joy is tinged by the failures of his magic and the damnation (albeit comic) of his scholar Miles:

Repentant for the follies of my youth,

That magic's secret mysteries misled, And joyful that this royal marriage Portends such bliss unto this matchless realm. (16.36-39) 
Bacon's magic has, from an early stage, been involved in self-interest and financial gain, and the celebration of his individual skill. ${ }^{36}$ It is this self-interest, too, that characterises Faustus. Fabell, in direct contrast to these recently revived stage conjurers, slips quietly offstage amid the clowns and reunited families with no return to the framing device. While some have read an ominous note in the open-endedness of Fabell's damnation, there is no sequel or consequence. The necromancer has been reconstituted as a member of the ensemble and his auctorial magic absorbed and redistributed; an act later embodied by the company in Prospero's freeing of Ariel and rejoining of human society. Merry Devil's magic creates a space for articulation of the importance of dramatic craft that neither destroys not exposes the author/conjurer, but instead makes him an integral and subservient part of his own craft.

\section{Works Cited.}

Abrams, William Amos, ed. The Merry Devil of Edmonton. Durham: Duke UP, 1942.

Bate, Jonathan, and Eric Ramussen, eds. William Shakespeare: Complete Works. Basingstoke: Macmillan, 2007.

Bennett, Nicola, ed. The Merry Devil of Edmonton. London: Nick Hern, 2000.

Bevington, David, and Eric Rasmussen, eds. Doctor Faustus. Manchester: Manchester UP, 1993.

Bowers, Fredson, ed. The Dramatic Works of Thomas Dekker. Cambridge: Cambridge UP, 1961. Vol. 1.

Brooke, C.F. Tucker, ed. The Shakespeare Apocrypha. Oxford: Clarendon Press, 1908. 
Fiehler, Rudolph. “'I Serve the Good Duke of Norfolk." Modern Language Quarterly 10.3 (1949), 364-67.

Greenblatt, Stephen. 'Shakespeare Bewitched.' Shakespeare and Cultural Traditions. Eds. Tetsuo Kishi, Roger Pringle and Stanley Wells. Newark: U of Delaware P, 1994, 17-53.

Horrell, Joseph. 'Peter Fabell and Dr. Faustus.' Notes and Queries 183:2 (1942).

James, D.G. The Dream of Prospero. Oxford: Clarendon Press, 1967.

Jowett, John, ed. Sir Thomas More. London: Methuen, 2011

Knapp, Jeffrey. Shakespeare Only. Chicago: University of Chicago Press, 2009.

Knutson, Roslyn Lander. The Repertory of Shakespeare's Company, 1594-1613. Fayetteville: University of Arkansas Press, 1991.

Masten, Jeffrey. Textual Intercourse. Cambridge: Cambridge UP, 1997.

McMullan, Gordon. Shakespeare and the Idea of Late Writing. Cambridge: Cambridge UP, 2007.

Melchiori, Giorgio, ed. The Merry Wives of Windsor. London: Thomson Learning, 2000.

Palmer, D.J. 'Magic and Poetry in Doctor Faustus.' Doctor Faustus: A Casebook. Ed. John Jump. Glasgow: Macmillan, 1969. 188-203.

Rutter, Tom. 'Introduction: The Repertory Approach.' Early Theatre 13.2 (2010), 12132.

Seltzer, Daniel, ed. Friar Bacon and Friar Bungay. London: Edward Arnold, 1963.

Stern, Tiffany. Rehearsal from Shakespeare to Sheridan. Oxford: Oxford UP, 2000.

Traister, Barbara Howard. 'Dealing with Dramatic Anonymity: The Case of The Merry Devil of Edmonton'. Anonymity in Early Modern England: 'What's in a Name?', 
eds. Janet Wright Starner and Barbara Howard Traister. Farnham: Ashgate, 2011.

99-111.

Wiles, David. Shakespeare's Clown. Cambridge: Cambridge UP, 1987.

\footnotetext{
${ }^{1}$ Nicola Bennett, ed., The Merry Devil of Edmonton (London: Nick Hern, 2000)

2 Bennett, xii.

3 The major candidates are Shakespeare, to whom the play was first attributed in a volume marked "Shakespeare, Vol. 1" belonging to the library of King Charles I in the 1630s; and Thomas Dekker, who is the preferred candidate of William Amos Abrams in the most important (but dated) critical edition of the play (Durham: Duke UP, 1942).

4 Tom Rutter offers a useful overview in "Introduction: The Repertory Approach". Early Theatre 13.2 (2010), 121-32. For individual studies, see especially Roslyn Knutson, Scott McMillin and Sally-Beth Maclean, The Queen's Men and Their Plays (Cambridge: Cambridge UP, 1998), and Lucy Munro, Children of the Queen's Revels (Cambridge: Cambridge UP, 2005).

${ }^{5}$ As convincingly argued by Rudolph Fiehler, who points out that all variations on the character - Fastolf, Falstaff and Oldcastle - were associated at some point with Mowbray/Norfolk. "II Serve the Good Duke of Norfolk." Modern Language Quarterly 10.3 (1949), 364-67.
}

${ }^{6}$ See, for example, David Wiles, Shakespeare's Clown (Cambridge: Cambridge UP, 1987). The play's Arden editor, Giorgio Melchiori, is among those who argue that the part is too large for Kempe to have played (London: Thomson, 2000), 84n. Regardless, it is the case that between Hamlet (c.1599) and the closing of the theatres in 1603, the company's output (including Twelfth Night and Troilus and Cressida) splits leading and comic roles among a number of relatively equally-weighted characters. With the re-opening of the theatres in 1604 , and the performance of plays such as Sejanus and Othello, a growing number of plays reintroduced major leading roles.

7 C.F. Tucker Brooke, ed., The Shakespeare Apocrypha (Oxford: Clarendon Press, 1908).

8 The apparent popularity of Pistol in 2 Henry IV, advertised on the 1600 first quarto, prefigures this movement towards a distribution of comic roles; and the survival of Pistol into Henry $V$ along with other comic characters such as Bardolph, Nym and Fluellen sees a more modest broadening of comic roles within a history play.

9 This use of magic as catalyst would be implicit, too, in Macbeth.

10 Stephen Greenblatt, "Shakespeare Bewitched.” Shakespeare and Cultural Traditions. Eds. Tetsuo Kishi, Roger Pringle and Stanley Wells (Newark: U of Delaware P, 1994), 29.

${ }^{11}$ Jeffrey Knapp, Shakespeare Only. Chicago: University of Chicago Press, 2009, 28-9.

12 Knapp, 29.

13 "You shall not sit in a Gallery, when your Comedies and Enterludes have entred their Actions, and there make vile and bad faces at euerie lyne, to make Gentlemen have an eye to you [...] you must forsweare to venter on the stage, when your Play is ended, and to exchange curtezies, and complements with Gallants in the Lordes rooms." (5.2.298-301, 303-5). Fredson Bowers, ed. The Dramatic Works of Thomas Dekker (Cambridge: Cambridge UP, 1961) Vol. 1.

14 There has recently been some interest in assigning Thomas More to the repertory of the Chamberlain's/King's Men around 1602; an assignation I choose not to pursue here, but would have interesting implications for the staging of authorial paradigms. More - in the 
form presented to us in the extant text - is one of the largest parts in the early modern drama; and yet he is explicitly an actor-author throughout the text, contributing to and generating performance. See John Jowett, ed., Thomas More (London: Methuen, 2011), esp. 88-96 and 100-3.

15 The connections are best outlined in Joseph Horrell, "Peter Fabell and Dr. Faustus." Notes and Queries 183:2 (1942), 36.

16 Roslyn Lander Knutson, The Repertory of Shakespeare's Company, 1594-1613

(Fayetteville: University of Arkansas Press, 1991), 90.

17 Barbara Howard Traister, 'Dealing with Dramatic Anonymity: The Case of The Merry Devil of Edmonton'. Anonymity in Early Modern England: 'What's in a Name?', eds. Janet Wright Starner and Barbara Howard Traister (Farnham: Ashgate, 2011), 106.

18 Cf. Faustus, B-text, 5.2.138-91. David Bevington and Eric Rasmussen, eds., Doctor Faustus (Manchester: Manchester UP, 1993). The extract also recalls the Ghost's words to Hamlet "And each particular hair to stand on end, / Like quills upon the fretful porpentine" (1.5.2324). Shakespeare quotes taken from Jonathan Bate and Eric Rasmussen, eds., William Shakespeare: Complete Works (Basingstoke: Macmillan, 1997).

${ }^{19}$ Prospero is, of course, extensively linked to Shakespeare biographically throughout criticism, the conjurer's abjuration of his art read inevitably as Shakespeare's farewell to the stage. This commonplace has been interestingly revisited from a post-structural perspective by Jeffrey Masten, Textual Intercourse (Cambridge: Cambridge UP, 1997), 107-11, and Gordon McMullan, Shakespeare and the Idea of Late Writing (Cambridge: Cambridge UP, 2007), esp. 78-81, who both critique the power of the biographical narrative over interpretation.

${ }^{20}$ D.J. Palmer, "Magic and Poetry in Doctor Faustus." in Doctor Faustus: A Casebook, ed. John Jump (Glasgow: Macmillan, 1969), 189.

21 See Merry Devil, Induction 27-9.

22 The magician as the creator of frameworks of performance and storytelling is, of course, later revisited by Shakespeare and the King's Men in The Tempest.

23 Palmer, 191.

24 This promise at 1.2.190-200 is not specifically geared towards an aspect of the problem in question, but instead is aimed at causing "carriers' jades", "milk-maids" and "prentices" to lose their way. It functions as a dramatic assertion of the magician's power, his ability to create disorder and un-write normative behaviours. It is only in retrospect that the confusion of the Act 4 evening excursion is related to this statement.

25 The scene can be contrasted to the treatment of confusion in the magical forest in $A$ Midsummer Night's Dream, where Puck is the visible orchestrator of Lysander and Demetrius's failure to find one another. Again, the dramatist appeals to memories of the company's earlier stagings of magic, which are then deliberately not realised in performance.

${ }^{26}$ We might interestingly compare D.G. James's note that at no point in the play "do we see Prospero engaged in magical ceremonies and incantations and calling up spirits to his service [...] we also nowhere see him as the magical 'operator'”. The Dream of Prospero (Oxford: Clarendon Press, 1967), 64.

27 Horrell, 36. Compare Bacon and Bungay's interventions in the love triangle of Edward, Lacy and Margaret, where their actions are overtly necromantic throughout.

${ }^{28}$ For historical context on the dramatic author's role, see Tiffany Stern, Rehearsal from Shakespeare to Sheridan (Oxford: Oxford UP, 2000) 69-70, which considers the instructional role of the author; popularised, inevitably, by John Madden's Shakespeare in Love (1998). ${ }^{29}$ I am indebted to Traister for this point (private communication). 
30 Daniel Seltzer, ed., Friar Bacon and Friar Bungay (London: Edward Arnold, 1963).

31 There may be a cross-reference to be made here to Bronwyn's paper?

32 Traister, 108.

${ }^{33}$ Fabell's "necromantic gaiety [...] is made no more of later, having no structural connection wit the plot the play" (35).

${ }^{34}$ See, for example, James 59-68.

35 Knutson, 89.

${ }^{36}$ See especially Edward's promises of "living and lands to strength thy college state" (5.89) in order to break up the true love of Lacy and Margaret, casting Bacon as a magician for hire. Even his project for the national good ultimately serves "Friar Bacon's weal;/ The honor and renown of all his life." (11.25-6). 